\title{
Cross-sectional Study on Technological Pedagogical Content Knowledge (TPACK) of Mathematics Teachers
}

\author{
Nancy D. Abunda \\ College of Education, Visayas State University, VSU, Visca, Baybay City, Leyte, 6521-A, Philippines
}

Received September 26, 2020; Revised November 17, 2020; Accepted November 29, 2020

\section{Cite This Paper in the following Citation Styles}

(a): [1] Nancy D. Abunda, "Cross-sectional Study on Technological Pedagogical Content Knowledge (TPACK) of Mathematics Teachers," Universal Journal of Educational Research, Vol. 8, No. 12A, pp. 7651 - 7659, 2020. DOI: 10.13189/ujer.2020.082551.

(b): Nancy D. Abunda (2020). Cross-sectional Study on Technological Pedagogical Content Knowledge (TPACK) of Mathematics Teachers. Universal Journal of Educational Research, 8(12A), 7651 - $7659 . \quad$ DOI: 10.13189/ujer.2020.082551.

Copyright $\odot 2020$ by authors, all rights reserved. Authors agree that this article remains permanently open access under the terms of the Creative Commons Attribution License 4.0 International License

\begin{abstract}
Teachers are best known to play a vital role in the educational system, especially in implementing a new curriculum. Adopting the Philippine's K-12 Curriculum requires continuous monitoring and assessment to ensure its programs' transparent improvement. This study examines the level of TPACK of mathematics preservice teachers (PSTs) and mathematics educators (MTEs) and determines whether a significant difference existed between them. Also, this study will establish a relationship between the MTE's TPACK and their technology integration. The participants of the study include 174 PSTs and 41 MTEs. The research instrument adopted considered central components of mathematical TPACK with Cronbach's alpha of 0.967. Results revealed that the mathematics PSTs had an average TPACK, while the MTEs' TPACK was high. A significant difference existed in the TPACK of PSTs and MTEs, indicating PSTs to be more exposed to learning the interconnections of these three knowledge bases, which can be seen demonstrated by MTEs in their instruction. A significant positive relationship existed between the MTEs' TPACK and their technology integration in class, indicating the regular use of technology in the instructional environment suggested higher TPACK among MTEs. The implications of the findings for practice on the teacher education programs are likewise discussed.
\end{abstract}

Keywords Cross-sectional Study, TPACK, Mathematics Preservice Teachers, Mathematics Educators

\section{Introduction}

TPACK focuses on the interrelated components of a teacher's knowledge of content (CK), pedagogy (PK), and technology (TK). It is considered a vital part of today's educational system as it addresses the growing demand for technology integration without giving less value to the content and its delivery for classroom instruction. TPACK is an emergent knowledge every teacher must be informed of to continuously track the new trends in education and be knowledgeable with the TPACK components to integrate into their classroom environment [13] effectively. Students also benefit from the TPACK framework since most of them are born in this technology era. They can work better by integrating technology and have a deeper conceptual grasp of the subject matter. Thus, by adding the concept of technology of Koehler \& Mishra [13] to Shulman's PCK model [24], students become more interactive in the learning process [5].

Technology in education uses modern tools and equipment to encourage more interactions among students, ensuring knowledge acquisition most efficiently and effectively [21]. However, Philippine's educational system performed worse on the 2017 Global Innovation Index, recorded a dismal rank at 113th place among the 127 countries. It ranked 76th among the 137 countries for the quality of mathematics and science education according to the Global Competitiveness Index for 2017-2018 [17]. According to the World Bank [17], the Philippine educational system underperformed East Asia counterparts and the Pacific. The students' scores were 
recorded below average in the international examinations, i.e., Programme for International Student Assessment (PISA) and the Trends in International Mathematics and Science Studies (TIMMS).

The country's current issues in the educational sector pave the way to the recent implementation of the $\mathrm{K}$ to 12 Basic Education Curriculum and the most talked ASEAN integration, which demands a lot of curriculum innovations [11]. In particular, secondary mathematics teachers need to embrace the change in mathematics, including integrating technology. Osinem [18] pointed out two of the positive social effects of technology-driven education on developing employable individuals and collaborative/cooperative learning. The utilization of technology in the teaching and learning process enables students to acquire skills needed in their future employment. It also enhances student-teacher-other stakeholder's relationships without the hindrance of geographical space [18]. The DepEd K-12 Curriculum Guide for Mathematics [14] issued by the Department of Education, recognized appropriate mathematics tools in teaching the subject. These include concrete and manipulative objects, measuring devices, calculators and computers, smartphones and tablet PCs, Internet, interactive whiteboards, mathematics software packages (e.g., educational dynamic programs such as GeoGebra, Matlab, Bagatrix, Graphmatica, and others).

Accompanying the curriculum innovations has been the agenda of strengthening quality teaching at all education systems throughout the country. According to the study conducted by Proctor, Finger, \& Albion [20] cited an example of the McKinsey report indicated that "The quality of an education system cannot exceed the quality of its teachers." Teachers are best known for their primary role in educating a child. It has been said that the teachers' teaching style in explaining mathematics depends mainly on their conceptual grasp acquired during their college classes. They often teach as they were taught and modeling themselves after their college mathematics teachers [2]. "Quality teaching requires developing a nuanced understanding of the complex relationship between technology, content, and pedagogy, and using this understanding to develop appropriate, context-specific strategies and representations" [13]. A teacher who aims to achieve a successful technology integration in the teaching - and learning process needs to consider all these interrelated components other than just a sole subject matter, pedagogy, or technology expert. Preparing preservice teachers for ICT-based classroom instruction attracts more attention for many teacher educations institutes [3]. Preservice teachers will be future mathematics teachers of today's 21 st-century learnerswho are geared to be an excellent critical thinker, problem solver, communicator, collaborator, creative, innovative, and technologically literate [20]. Reference [2] indicated that several units or courses during college days have touched on using ICT by demonstrating or suggesting how these could be integrated into instruction. However, preservice teachers narrated that only a few lecturers have integrated ICT for classroom use. We have seen the gap between educators trying to teach only theories with these preservice teachers other than what is being transpired during their classroom applications. There is a weak connection between what educators aim to achieve for their preservice teachers from what they ought to teach and model in their instructional environment. An Australian project called Teaching Teachers for the Future, with its partnership in ICT learning study, argued that preservice teachers are the future leaders of ICT-rich provisions in schools. They should be at the vanguard of change; their ideas and enthusiasm for ICT-based instruction are crucial [2].

As technology integration is considered essential preparation for preservice teachers, there is a need to assess their Technological Pedagogical Content Knowledge (TPACK) to audit our graduates' current status. The study will also establish whether the utilization of technology in education is translated into teaching practice by mathematics teacher educators. This critical finding can be fed back to them to spearhead their professional growth. Thus, this study intends to assess the level of technological pedagogical content knowledge of mathematics preservice teachers (PSTs) and mathematics teacher educators (MTEs).

Specifically, this study will be guided by these research questions:

1. What is the level of mathematics preservice teachers (PSTs) and mathematics teacher educators (MTEs)' TPACK?

2. Is there a significant difference between the TPACK of the PSTs and MTEs?

3. Is there a significant relationship between MTEs' TPACK and their technology integration in class?

4. What are technologies used by the MTEs and its frequency of use?

5. What is the MTEs' reason(s) for using technology in their mathematics classes?

\section{Materials and Methods}

This study utilized a descriptive-correlational research design. The participants were the one hundred seventy-four (174) mathematics PSTs who were officially enrolled in the second semester of the school year 2016-2017 and forty - one (41) MTEs handling mathematics classes for the math major students in the Bachelor of Secondary Education Curriculum. Of these 174 students, 95\% are regular students, while 5\% are irregular students. The study took place at Visayas State University in Region 8. In the development of the instrument of this study, the researcher adopted the 
instrument from $[12,15,16,23,25]$ and put into consideration Guerrero's [8] four central components of mathematical TPACK such as (1) Conception and Use of Technology, (2) Technology-Based Mathematics Instruction, (3) Management, and (4) Depth and Breadth of Mathematics Content. This study's TPACK assessment tool consisted of 52 items distributed to the four components of the mathematical TPACK. The instrument used a Researcher's Rating Scale with the following Descriptive Ratings and Corresponding Descriptions in the Participant's TPACK: Very Low (0-10\% competent), Low (11-30\% competent), Average (31-70\% competent), High (71-90\% competent), and Very High (91-100\% competent). The survey instrument also included questions regarding the technologies used by the MTEs in their mathematics classes, frequency of use, and reason(s) for using those technologies. The instrument also used a scale with the following descriptive ratings and corresponding descriptions in the participant's frequency of use of technology integration: Never (not used this technology at all), Rarely (used only once in a semester), Sometimes (used twice or thrice in a semester), Often (used four to ten times in a semester), and Regularly (used more than ten times in a semester).

The survey instrument undergone validation from six mathematics experts and was pilot tested to the fourth-year mathematics major education students and mathematics teacher educators at West Visayas State University, Iloilo City. There were about 93 PSTs and 27 MTEs as to the sample size used for the pilot test. The instrument was found out to be reliable, with an overall Cronbach's alpha of 0.967. Concerning the tool's sub-constructs, the reported Cronbach's alpha is as follows: Conception and Use of Technology - 0.827, Technology-based Mathematics Instruction - 0.907, Management - 0.949, and Depth and Breadth of Mathematics Content -0.912 .

The researcher asked permission from the University President and Dean of the College of Education at West Visayas State University to validate the survey instrument by the fourth-year mathematics major education students and mathematics teacher educators after they have signed the consent form. The result of the validation process was analyzed, and necessary revisions of the instrument were made. After the instrument's validation, the researcher administered it to fourth-year Bachelor of Secondary Education (BSEd) major in mathematics students and the mathematics teacher educators handling mathematics classes in the BSEd curriculum after granted permission by the VSU President and the Dean of the College of Education. A signed consent form from the participants was collected indicated the participation of the participants in the study. The conduct of the survey instrument consumed more or less an hour.

A focus group discussion was also conducted to selected PSTs and MTEs to further substantiate the survey instrument results.

After collecting the data gathered, mean and standard deviations were used to determine the levels of TPACK of mathematics PSTs and the MTEs, the technologies that the MTEs used in their mathematics classes, and the duration of their use of these technologies. Percentages were also used to identify the MTEs' reasons for using technology. For inferential analyses, a t-test for Two Independent Samples was used to ascertain if there would exist a significant difference in the mathematics PSTs and MTEs' TPACK and Spearman Rank-Order Correlation Coefficient if there would exist significant relationships between the MTEs' TPACK and their use of technology in Mathematics classes.

\section{Results and Discussions}

In general, this study aims to describe the TPACK level of mathematics PSTs and MTEs handling mathematics classes in the BSED mathematics curriculum.

\section{Level of Mathematics Pre-Service Teachers and Mathematics Teacher Educators' Technological Pedagogical Content Knowledge.}

The results of PSTs' and MTEs' TPACK are shown in Table 1. By inspection of the means, the mathematics PSTs had average TPACK $(\mathrm{M}=3.47, \mathrm{SD}=0.94)$, which implies that the PSTs were $31-70 \%$ competent to teach technology-based mathematics instruction. Some components of the PSTs' TPACK demonstrated high levels such as the Conception and Use of Technology $(\mathrm{M}=3.79, \mathrm{SD}=0.87)$ and on the Depth and Breadth of Mathematics Content $(\mathrm{M}=3.65, \mathrm{SD}=0.91)$. According to Guerrero [8], the first component (Conception and Use of Technology) relates technology to pedagogical content knowledge by focusing on how the teacher can use technology to make the subject matter more comprehensible and accessible to students. This component becomes a basis for decision-making related to instructions and curricula that teachers make in rendering the subject matter more accessible to students. The final component (Depth and Breadth of Mathematics Content) relies on the teachers' knowledge of mathematics content and embracing their responsibility to understand their content areas with both breadth and depth due to technology integration. The finding above agrees with the results of the study of [20], wherein 345 preservice teachers showed high levels of interest in and on technology integration both for personal and professional purposes. However, they believed that they utilized ICT for teaching and learning purposes only, other than their strong conception of ICT's value to improve students' learning outcomes. The result agrees with [22], which revealed that preservice had the lowest score in TPACK than with the in-service teachers. Although the PSTs 
showed a high level of self-perceived competence of their technological knowledge, they still found it difficult to apply some technologies in their classroom instruction. The result is evident in the other two components, which only showed an average level: Technology-Based Mathematics Instruction $(\mathrm{M}=3.28, \quad \mathrm{SD}=0.94)$ and Management $(\mathrm{M}=3.16, \mathrm{SD}=1.12)$. The second component (Technology-based Mathematics Instruction) includes teachers' knowledge of and ability to maneuver through various instructional issues specifically related to technology supporting mathematics teaching and learning [8]. The third component (Management) covers management issues related to teaching and learning with technology, including a teacher's understanding of how to handle students' attitudes toward technology and their behavior due to using technology. Ten mathematics PSTs were randomly selected during the focus group discussion to explain the second and third components' average levels. Nine out of ten students said that less is given the emphasis on the use of technology as part of their teacher's instructional repertoire, and most of their teachers do not have the skill to do some troubleshooting for minor technical problems (i.e., network problems and operating the LCD projector). Further, students narrated that some of their teachers do not use the PowerPoint Presentation effectively.

Table 1. Mathematics Pre-service Teachers' and Mathematics Educators' TPACK

\begin{tabular}{|c|c|c|c|}
\hline Groups & $S D$ & $M$ & $\begin{array}{c}\text { Descriptive } \\
\text { Rating }\end{array}$ \\
\hline \multicolumn{4}{|l|}{ Mathematics PSTs } \\
\hline $\begin{array}{c}\text { Conception and Use of } \\
\text { Technology }\end{array}$ & 0.87 & 3.79 & High \\
\hline $\begin{array}{c}\text { Technology-Based } \\
\text { Mathematics Instruction }\end{array}$ & 0.94 & 3.28 & Average \\
\hline Management & 1.12 & 3.16 & Average \\
\hline $\begin{array}{l}\text { Depth and Breadth of } \\
\text { Mathematics Content }\end{array}$ & 0.91 & 3.65 & High \\
\hline Over-all PSTs TPACK & 0.94 & 3.47 & Average \\
\hline \multicolumn{4}{|l|}{ MTEs } \\
\hline $\begin{array}{c}\text { Conception and Use of } \\
\text { Technology }\end{array}$ & 0.75 & 3.93 & High \\
\hline $\begin{array}{c}\text { Technology-Based } \\
\text { Mathematics Instruction }\end{array}$ & 0.63 & 3.99 & High \\
\hline Management & 0.87 & 3.63 & High \\
\hline $\begin{array}{l}\text { Depth and Breadth of } \\
\text { Mathematics Content }\end{array}$ & 0.79 & 4.15 & High \\
\hline Over-all MTEs TPACK & 0.76 & 3.93 & High \\
\hline $\begin{array}{c}\text { Mathematics Teacher's } \\
\text { TPACK }\end{array}$ & 0.72 & 3.69 & High \\
\hline
\end{tabular}

Note. 4.51-5.00, Very High - 91-100\% competent; 3.51-4.50, High 71-90\% competent; $2.51-3.50$, Average - 31-70\% competent; $1.50-2.49$, Low - 11-30\% competent; $1.00-1.49$, Very Low - 0-10\% competent

On the other hand, the MTEs had high TPACK $(\mathrm{M}=3.93, \mathrm{SD}=0.76)$, which means that the MTEs were $71-90 \%$ competent to teach technology-based mathematics instruction. All of the MTEs' TPACK components obtained high means: Conception and Use of Technology $\quad(M=3.93, \quad S D=0.75), \quad$ Technology-based Mathematics Instruction $\quad(\mathrm{M}=3.99, \quad \mathrm{SD}=0.63)$, Management $(\mathrm{M}=3.63, \mathrm{SD}=0.87)$, and Depth and Breadth of Mathematics Content $(\mathrm{M}=4.15, \mathrm{SD}=0.79)$. Reference [22] is in disagreement with this result. Their study revealed that in-service teachers had the lowest mean score in the technological knowledge domain. However, the result of this study is similar to the results of the study of [25], wherein 37 mathematics teacher educators from the ten state teacher education institutions in Central Luzon, Philippines, handling mathematics classes in the Bachelor of Secondary Education, Mathematics curriculum had high levels of technological pedagogical content knowledge. The MTEs considered themselves to be highly knowledgeable about content, pedagogy, and technology in mathematics teaching.

Nevertheless, when students were asked about how their mathematics educators used and integrated technology in their mathematics classes, most of them indicated that the mathematics teacher educators seldom used technology integration $(\mathrm{M}=2.08, \mathrm{SD}=0.84)$ in their mathematics classes. Based on [25] study, a discrepancy between the MTEs perceived TPACK and the students' perception of the MTEs' TPACK. The MTEs' high TPACK level did not reveal a transparent demonstration of the three essential knowledge bases: content, pedagogy, and technology.

\section{Difference in Mathematics Pre-service Teachers' and Mathematics Teacher Educators' Technological Pedagogical Content Knowledge}

t-test results in Table 2 shows that there exists significant differences in the three components of TPACK: (1) Technology-based Mathematics Instruction $(t=-4.65$, $\mathrm{p}=.000)$, (2) Management $(\mathrm{t}=-2.02, \mathrm{p}=.047)$, and (3) Depth and Breadth of Mathematics Content $(t=-2.62$, $\mathrm{p}$ $=.011$ ), between the mathematics PSTs and MTEs. On the other hand, no significant difference existed in one component - Conception and Use of Technology $(\mathrm{t}=-.78$, $\mathrm{p}=.441)$. The results indicated that the two groups' knowledge was similar in making educational technology decisions to make the subject matter more accessible and understandable. However, MTEs outperformed PSTs' knowledge to (1) maneuver through various instructional issues specifically on the use of technology in support of the mathematics teaching and learning process; (2) management issues specifically related to technology-based mathematics instruction; and (3) the teachers' breadth and depth of mathematics content knowledge as influenced of using technology in their instruction. The findings conformed to the study of [9], wherein in-service teachers and preservice teachers performed the same in decision-making about the use of educational technology. However, in-service teachers 
performed better than the preservice teachers in terms of depth, breadth, and practical, contextual, and pedagogical knowledge. Also, the authors of the study narrated their differences. Citing that "the rationales upon which preservice teachers based their instructional decisions were more superficial, uncritical, and relied largely on consideration of students and classroom-related facts of the case, compared to in-service teachers' responses, which were more detailed, better elaborated, more interpretive, and critical of the school context."

The results further revealed a significant difference in the general TPACK of PSTs and MTEs, $\mathrm{t}=2.87, \mathrm{p}=.005$. The result implies that the PSTs' TPACK and MTEs' TPACK were statistically different from each other. It can be inferred that the MTEs' TPACK is higher than that of the PSTs. The finding conforms to [22], indicating that math teachers' TPACK was significantly higher than preservice Math teachers' TPACK. The finding may also be supported by Bate et al. (2013), wherein the preservice teachers expressed sentiments about their experience in their undergraduate studies. They claimed less confidence to use mathematics software even though lengthy discussions on its use. These software or technology as a whole should be integrated into teachers' discussion of concepts or theories so that students can model these strategies in their actual field of teaching. The finding is also similar to Aquino's (2015) study; wherein there is a significant difference between the TPACK of preservice biology teachers and the perceived TPACK modeled by their faculty.

\section{Relationship between Mathematics Teacher Educators' Technological Pedagogical Content Knowledge and Their Use of Technology Integration}

Spearman's Rank-Order Correlation Coefficient results in Table 3 reveal a significant relationship between MTEs' TPACK and their use of technology integration ( $r=.929$, $\mathrm{p}=.000$ ). The computed $\mathrm{p}$-value is less than .001 . It can be inferred that the MTEs' TPACK is transparent to their use of technology in their mathematics instruction. The higher the MTEs' TPACK, the more frequent MTEs' usage and integration of technology into their mathematics classes. This finding is similar to the study of [25], wherein there was a moderate positive but significant linear correlation between the MTEs' level of TPACK and the extent of technology integration in mathematics classes $(r=0.50$, df $=35, \mathrm{p}<.01$ ).

Table 2. T-test Results for the Difference of the Mathematics Pre-service Teachers and Mathematics Educators' TPACK

\begin{tabular}{|c|c|c|c|c|c|c|c|}
\hline $\begin{array}{c}\text { Mathematical TPACK } \\
\text { Components }\end{array}$ & $\begin{array}{c}\text { Compared } \\
\text { Groups } \\
\end{array}$ & $N$ & $D f$ & Mean & $\begin{array}{c}\text { Mean } \\
\text { Difference } \\
\end{array}$ & $t$ & $\begin{array}{c}\text { Sig. } \\
\text { (2 tailed) }\end{array}$ \\
\hline \multirow{2}{*}{$\begin{array}{l}\text { Conception and Use of } \\
\text { Technology }\end{array}$} & PSTs & 174 & 213 & 3.79 & 0.14 & -.78 & .441 \\
\hline & MTEs & 41 & & 3.93 & & & \\
\hline \multirow{2}{*}{$\begin{array}{c}\text { Technology-Based } \\
\text { Mathematics Instruction }\end{array}$} & PSTs & 174 & 213 & 3.28 & 0.71 & $-4.65 * *$ & .000 \\
\hline & MTEs & 41 & & 3.99 & & & \\
\hline \multirow{2}{*}{ Management } & PSTs & 174 & 213 & 3.16 & 0.47 & $-2.02 *$ & .047 \\
\hline & MTEs & 41 & & 3.63 & & & \\
\hline \multirow{2}{*}{$\begin{array}{l}\text { Depth and Breadth of } \\
\text { Mathematics Content }\end{array}$} & PSTs & 174 & 213 & 3.65 & 0.50 & $-2.62 *$ & .011 \\
\hline & MTEs & 41 & & 4.15 & & & \\
\hline \multirow{2}{*}{ Over-all TPACK } & PSTs & 174 & 213 & 3.47 & 0.46 & $-2.87 *$ & .005 \\
\hline & MTEs & 41 & & 3.93 & & & \\
\hline
\end{tabular}

$* \mathrm{p}<.05$ Significant

$* * \mathrm{p}<.01$ Significant

$* * \mathrm{p}<.001$ Significant

Table 3. Spearman's rho Results for the Relationship of Mathematics Educators' TPACK and Use of Technology Integration

\begin{tabular}{|c|c|c|}
\hline & MTEs' TPACK & Use of Technology \\
\hline MTEs' TPACK & Spearman's rho & $.929^{*}$ \\
\hline & Sig & .000 \\
\hline & $N$ & 41 \\
\hline
\end{tabular}

$* \mathrm{p}<. .001$ Significant 


\section{Mathematics Teacher Educators' Frequency of Use of Technology Integration}

Technology in this study was divided into two categories: hardware and software. Hardware technologies refer to the tangible tools and equipment supporting mathematics instruction such as laptop/desktop, calculator, LCD projector, and others. In contrast, software technologies refer to the intangible tools and equipment that supports mathematics instruction, i.e., MS Word, MS Excel, MS Powerpoint, GeoGebra, Matlab, SPSS, Mathematica, and others of this type. As shown in Table 4, the study results revealed that Mathematica, Bagatrix, and Graphmatica were the identified software technologies used by the MTEs in their mathematics classes. Based on the results, the MTEs regularly used laptop/desktop $(\mathrm{M}=3.57, \quad \mathrm{SD}=0.57), \quad$ scientific calculator $\quad(\mathrm{M}=3.57$, $\mathrm{SD}=0.79)$, an $\mathrm{LCD}$ projector $(\mathrm{M}=3.57, \mathrm{SD}=0.54)$ for the hardware technology; a word processor, i.e., MS Word $(\mathrm{M}=3.71, \mathrm{SD}=0.49)$, and a presentation program, i.e., $\mathrm{MS}$ PowerPoint $(\mathrm{M}=3.71, \quad \mathrm{SD}=0.48)$ for the software technology. The result means that the MTEs used these technologies more than ten times in a semester. The MTEs used these technologies more than ten times in a semester. The MTEs often used a spreadsheet, i.e., MS Excel $(\mathrm{M}=3.29, \mathrm{SD}=0.95)$, GeoGebra $(\mathrm{M}=2.86, \mathrm{SD}=1.07)$, and website resources $(\mathrm{M}=2.86, \mathrm{SD}=1.46)$ for software technology. The result means that the MTEs used these technologies four to ten times in a semester. The MTEs sometimes used a MS

Table 4. Mathematics Educators' Frequency of Technology Integration

\begin{tabular}{|c|c|c|c|}
\hline $\begin{array}{c}\text { Category of } \\
\text { Technology }\end{array}$ & $\boldsymbol{S D}$ & $\boldsymbol{M}$ & $\begin{array}{c}\text { Descriptive } \\
\text { Rating }\end{array}$ \\
\hline HARDWARE & 0.90 & 3.14 & Often \\
\hline Laptop/ Desktop & 0.57 & 3.57 & Regularly \\
\hline Scientific Calculator & 0.79 & 3.57 & Regularly \\
\hline Graphing Calculator & 1.68 & 1.86 & Sometimes \\
\hline LCD Projector & 0.54 & 3.57 & Regularly \\
\hline IPOd & 0.00 & 0.00 & Never \\
\hline SOFTWARE & 1.03 & 1.93 & Sometimes \\
\hline A word processor & 0.49 & 3.71 & Regularly \\
\hline A spreadsheet & 0.95 & 3.29 & Often \\
\hline Presentation Program & 0.48 & 3.71 & Regularly \\
\hline Matlab & 1.13 & 0.57 & Rarely \\
\hline GeoGebra & 1.07 & 2.86 & Often \\
\hline SPSS & 1.13 & 0.57 & Rarely \\
\hline Website resources & 1.46 & 2.86 & Often \\
\hline Bagatrix & 1.73 & 1.00 & Rarely \\
\hline Mathematica & 0.76 & 0.29 & Never \\
\hline Graphmatica & 1.13 & 0.43 & Never \\
\hline
\end{tabular}

Note. 3.50-4.00, Regularly - used more than ten times in a semester; 2.50-3.49, Often - used four to ten times in a semester; $1.50-2.49$, Sometimes - used twice or thrice in a semester; $0.50-1.49$, Rarely - used only once in a semester; $0.00-0.49$, Never - not used this technology at all

Excel $(\mathrm{M}=3.29, \quad \mathrm{SD}=0.95), \quad \mathrm{GeoGebra} \quad(\mathrm{M}=2.86$,
$\mathrm{SD}=1.07)$, and website resources $(\mathrm{M}=2.86, \mathrm{SD}=1.46)$ for software technology. The result means that the MTEs used these technologies four to ten times in a semester. The MTEs sometimes used a graphing calculator $(\mathrm{M}=1.86$, $\mathrm{SD}=1.68$ ) for the hardware technology, which means that this technology was used twice or thrice in a semester. The result also showed that the MTEs rarely used Matlab $(\mathrm{M}=0.57, \mathrm{SD}=1.13), \quad$ SPSS $(\mathrm{M}=0.57, \mathrm{SD}=1.13)$, and Bagatrix $(\mathrm{M}=1.00, \mathrm{SD}=1.73)$ for software technology. The result means that the MTEs used these technologies only once in a semester. Lastly, the MTEs never used an iPod $(\mathrm{M}=0.00, \quad \mathrm{SD}=0.00), \quad$ Mathematica $\quad(\mathrm{M}=0.29$, $\mathrm{SD}=0.76)$, and Graphmatica $(\mathrm{M}=0.43, \mathrm{SD}=1.13)$, which means that the MTEs did not use this technology at all in their mathematics classes. Overall, the MTES often $(\mathrm{M}=3.14, \mathrm{SD}=0.90)$ used hardware technologies, which means an average of four to ten times in a semester; and sometimes $\quad(\mathrm{M}=1.93, \quad \mathrm{SD}=1.03)$ used software technologies in their mathematics classes, which means an average of twice or thrice in a semester.

\section{Mathematics Teacher Educators' Reasons for Using Technology}

When MTEs were asked about their purpose for integrating technology in their BSEd-Mathematics classes, some MTEs indicated various reasons, as showed in Table 5. Results revealed that a total of $35(85 \%)$ indicated numerical computation, $41(100 \%)$ graphical presentation, $23(56 \%)$ interactive learning, $41 \quad(100 \%)$ tabular presentation, and $11(27 \%)$ symbolic manipulation. Most of the MTEs' purpose for integrating technology in their mathematics classes were for graphical and tabular presentations. The MTEs' use of graphical presentation in a simple, clear, and effective manner of the quantitative data facilitates the comparisons of values, trends, and relationships (In \& Sangseok, 2017.) Also, MTEs use a tabular presentation to organize data for further statistical treatment and decision-making. They use technologies that would help them present complicated figures accurately or graphs to lessen students' misconceptions of the concepts introduced (In \& Sangseok, 2017.) According to a study conducted by Goos (2010), teachers use technology to support effective mathematics teaching and learning, and these enhanced student's opportunities to use technology to (1) improve speed, accuracy, and access to a variety of mathematical presentations, (2) improve the display of mathematical solution processes and support student's collaborative work, and (3) support new goals or teaching methods for a mathematics course. In an article issued by the Center for Technology in Learning (2007), there are two main reasons why teachers use technology: computation and representation. Technology can reduce the effort devoted to tedious computations and increase students' focus on more important mathematics. Equally important, technology can represent mathematics in ways that help students 
understand concepts. In combination, these features can enable teachers to improve both how and what students learn.

Table 5. Mathematics Educators' Reasons for Using Technology

\begin{tabular}{|c|c|c|}
\hline Reasons & $\boldsymbol{N}$ & Percentage (\%) \\
\hline Numerical Computation & 35 & 85 \\
\hline Graphical Presentation & 41 & 100 \\
\hline Interactive Learning & 23 & 56 \\
\hline Tabular Presentation & 41 & 100 \\
\hline Symbolic Manipulation & 11 & 27 \\
\hline
\end{tabular}

The findings of this study have to be seen in light of some limitations that could be addressed in future research. This study did not include the participants profile as one of the variables under study. Quantitative variables such as average age, sex distribution, academic abilities, and others were not included under the investigated variable.

\section{Conclusions}

Most of the mathematics preservice teachers had an average technological pedagogical content knowledge, which means that they are only $31-70 \%$ competent to teach technology-based mathematics instruction. The results may be credited to their current status as inexperienced in the field of education. The PSTs might not have acquired enough knowledge of teaching pedagogy, especially on their management capabilities, where they had the lowest mean among the other three components. The improvement of their TPACK seems to have taken a long time, if not in a few years, and they need to move beyond teacher preparation programs into the teaching profession's actual field to build their TPACK [20]. On the other hand, mathematics teacher educators have a high level of TPACK, which reported $71-90 \%$ competent to teach technology-based mathematics instruction. The MTEs might have been well exposed and have attended various seminar workshops or training, where learning of these three important knowledge bases was given greater emphasis. With these, our next target is to transfer this HIGH TPACK of MTEs to our PSTs, so when they are in the actual field of teaching, they can imitate and might as well use and demonstrate appropriate technology in their mathematics lessons.

\section{Recommendations}

Based on the findings and conclusions of this study, the following recommendations are advanced:

1. Teacher education institutions should provide a program of opportunities [for teachers and students] to acquire the knowledge and experiences needed to integrate appropriate technology in teaching and learning mathematics.

2. Universities should procure and invest in purchasing equipment needed to improve technology integration in the curriculum.

3. Teacher education institutions, curriculum designers, and policymakers may use the baseline data on the TPACK of mathematics PSTs and MTEs to develop potential knowledge of planning and design learning materials that may exhibit teachers' TPACK teaching-learning process.

\section{Implications for Practice}

1. The average TPACK of mathematics PSTs implies that schools, institutions, and colleges offering teacher education programs must regularly assess students' technology experiences in the BS programs. This will ensure that all preservice teachers have the necessary knowledge bases (TPACK) and confidence to incorporate technology into the curriculum, especially in this technology era, where students are considered digital natives [19].

2. The high TPACK of MTEs implies that college departments and universities must nurture and even enhance this knowledge by providing them with seminar-workshops on how to capitalize on these knowledge bases so that educators could demonstrate and make this transparent to the students.

3. The significant difference in the technological-pedagogical content knowledge of mathematics preservice teachers and mathematics teacher educators implies that mathematics PSTs need to be more exposed to learning the interconnections among the three knowledge bases: content, pedagogy, and technology; which can be seen demonstrated by the MTEs in their instruction. Mathematics preservice teachers are soon-to-be teachers in the actual teaching field, and most of what they can offer to their class is model from their previous instructors or professors in class.

4. The significant relationship between the mathematics teacher educators' technological pedagogical content knowledge and the use of technology integration in their mathematics classes imply that the regular use of appropriate technology in the instructional environment increases the level of TPACK among MTEs.

5. The mathematics teacher educators' regular use of hardware technologies and sometimes the use of software technologies in their mathematics classes imply that mathematics educators must be more willing to learn and embrace emerging technologies that have potential use in the instructional environment. 
6. The identified various reasons for mathematics teacher educators' use of technology in their mathematics classes imply that technology helps students and teachers get answers more quickly and accurately, but it has more to offer. If technological tools are considered providing access to new understandings of relations, processes, and purposes, technology's role relates to a conceptual construction kit rather than efficiency.

\section{Acknowledgment}

The author would like to express her sincerest gratitude to Visayas State University, for its continuous support to their faculty's professional development; to West Visayas State University, for the wonderful experienced of the author during her graduate study; to the Department of Science and Technology Science Education Institute (DOST - SEI), for the scholarship and assistance that immensely helped the researcher in finishing this study; Dr. Elvira L. Arellano, researcher's adviser, for her supervision, pieces of advice, and continuous guidance from the very early stage of this research as well as for giving the researcher extraordinary experiences throughout the work and providing her untiring encouragement and support; the researcher's hubby Rhenevil, for his everlasting love, untiring patience, genuine care, inspiration, trust, prayers, and encouragement; Nia \& Natnat, the researcher's lovely kiddos; the researcher's family, friends, colleagues; and most of all, the Almighty God for being there throughout all the tests and challenges; Indeed you are always faithful to your promise in me in Philippians 4:13, I can do all things through CHRIST who gives me strength; to HIM be all glory!

\section{REFERENCES}

[1] A. Aquino. Self-efficacy on Technological, Pedagogical and Content Knowledge (TPACK) of Biological Science Pre-Service Teachers. Asia Pacific Journal of Multidisciplinary Research, Vol. 3, No.4, 2015.

[2] F. Bate, L. Day, Macnish, J. Conceptualizing Changes to Pre-Service Teachers' Knowledge of how to Best Facilitate Learning in Mathematics: A TPACK Inspired Initiative. Australian Journal of Teacher Education, Vol. 38, No. 5, 2013.

[3] C. S. Chai, J. H. L. Koh, C-C. Tsai. Facilitating Preservice Teachers' Development of Technological, Pedagogical and Content Knowledge (TPACK). Educational Technology \& Society, Vol. 13, No. 4, pp. 63-73, 2010

[4] K. Cirillo. Tackling Math with Technology in the Philippines, Innovation on learning and localization,
Philippines, 2014.

[5] A. Craig. The Importance of TPACK and why I am drawn to it! Retrieved from https://medium.com/@AJ_Craig/the-imp ortance-of-tpack-868c0ee44fc6

[6] S. Ghavifekr, W. A. W. Rosdy. Teaching and learning with technology: Effectiveness of ICT integration in schools. International Journal of Research in Education and Science, Vol. 1, No. 2, pp. 175 - 191, 2015

[7] M. Goos. Using technology to support effective mathematics teaching and learning: What counts? Australian Council for Educational Research Conference Proceedings, pp. 67 - 70, 2010.

[8] S. Guerrero. Technological Pedagogical Content Knowledge in the Mathematics Classroom. Journal of Digital Learning in Teacher Education, Vol. 26, No. 4, 2010.

[9] J. Harris, M. J. Hofer. Differentiating TPACK-Based Learning Materials for Preservice and Inservice Teachers. In P. Resta \& Smith (Eds.), Proceedings of Society for Information Technology \& Teacher Education International Conference, pp. 1656-1665, 2017.

[10] J. In, L. Sangseok. Statistical data presentation. Korean Journal of Anesthesiology, Vol. 70, No. 3, pp. 267 - 276, 2017.

[11] Issues Regarding the Educational System. K 12 Academics, 2020.

[12] T. Kartal, B. Kartal, G. Uluay. Technological Pedagogical Content Knowledge Self-Assessment Scale (TPACK-SAS) for Pre-Service Teachers: Development, Validity and Reliability. International Journal of Eurasia Social Sciences, Vol. 7, No. 23, pp. 1 - 36, 2016.

[13] M. J. Koehler, P. Mishra. Technological Pedagogical Content Knowledge: A framework for teacher knowledge. Teachers College Record, Vol. 108, No. 6, pp. 1017 - 1054, 2006.

[14] K to 12 Mathematics Curriculum Guide, 2013.

[15] G. A. Landry. Creating and Validating an Instrument to Measure Middle School Mathematics Teachers' Technological Pedagogical Content Knowledge (TPACK). Doctoral dissertation from the University of Tennessee, 2010.

[16] N. Onal. Development, Validity and Reliability of TPACK Scale with Pre-Service Mathematics Teachers. International Online Journal of Educational Sciences, Vol. 8, No. 2, 2016.

[17] J. L. Orlanda. Current Issues on Philippine Education, 2018.

[18] E. O. Osinem. Social Impact of technology-Driven Education. Paper presented at the International Confab organized by Chartered Institute of Educational Practitioners, UK, on Innovative Teaching Strategies at Educators House, 2 Justice Sowemimo Street Asokoro, Abuja, Nigeria, 2019.

[19] M. Prensky. Digital natives, Digital Immigrants. On the Horizon (MCB University Press, Vol. 9 No. 5, 2001.

[20] R. J. Proctor, G. Finger, P. Albion. Auditing the TPACK capabilities of final year teacher education students: Are they ready for the 21 st century? Paper presented at the Digital Diversity Conference, 2010.

[21] R. Raja, P. C. Nagasubramani. Impact of Modern 
Technology in Education. Journal of Applied and Advanced Research, Vol. 3, No. 31, 2018.

[22] F. Saltan, K. Arslan. A comparison of in-service and pre-service teachers' technological pedagogical content knowledge self-confidence. Cogent Education, Vol. 4, No. 1, 2017.

[23] D. A. Schmidt, E. Baran, A. D. Thompson, P. Mishra, M. J. Koehler, T. S. Shin. Technological pedagogical content knowledge (TPACK) the development and validation of an assessment instrument for preservice teachers. Journal of Research on Technology in Education, Vol. 42, No 2, pp.
$123-149,2009$.

[24] L. S. Shulman. Knowledge and teaching: Foundations of the new reform. Harvard Education Review, No. 57, pp. 1 - 22, 1987.

[25] F. V. Tamoria. Extent of Technology Integration in Mathematics Teacher Education among State Institutions in Central Luzon. AsTEN Journal of Teacher Education, Vol. 1, No. 1, 2016.

[26] E. C. Torrefranca. Development and Validation of Instructional Modules on Rational Expressions and Variations. The Normal Lights, Vol. 11, No. 1, 2017. 